www.cjes.eu

Birlesik Dunya Arastrma Cypriot Journal of Educational

\title{
Teaching Kazakh novels with electronic book applications; Teacher and student opinions.
}

Almas Naimanbaev ${ }^{a *}$,Candidate of philological sciences, doctoral student, Abai Kazakh National Pedagogical University, Almaty, Kazakhstan, Address: 13 Dostyk Ave., Almaty, https://orcid.org/0000-0003-1732$\underline{8830}$

Darikha A. Satemirova ${ }^{b}$,Candidate of philological Sciences,Abai Kazakh National Pedagogical University, Almaty, Kazakhstan, Address: 13 Dostyk Ave., Almaty https://orcid.org/0000-0002-7232-3947

Tamaev Alpysbay ${ }^{c}$,Candidate of Pedagogical Sciences, Abai Kazakh National Pedagogical University, Almaty, Kazakhstan, Address: 13 Dostyk Ave., Almaty https://orcid.org/0000-0002-5046-0043

Salamatova Rakhat ${ }^{d}$,Candidate of philological Sciences,Associate professor of the Department "Kazakh language and literature",Taraz regional university named after M. H. Dulati, Taraz, Kazakhstan, Address: 60 Suleimanov STR., Taraz, 080000 https://orcid.org/0000-0002-2556-2611

Baltabay Abdigazievich e 'Doctor of philology, professor Abai Kazakh National Pedagogical University, Almaty, Kazakhstan, Address: 13 Dostyk Ave., Almaty https://orcid.org/0000-0002-4191-0831

Aliya Nazarova ${ }^{f}$,Master of Arts in humanities(acting), Kazakh National University. Kazakh National University. AlFarabi Kazakh National University, Address: 71 Al-Farabi Ave., https://orcid.org/0000-0002-4064-9993

\section{Suggested Citation:}

Naimanbaev, A., Satemirova, D. A., Alpysbay,T., Rakhat, S., Abdigazievich, B.\& Teaching Kazakh novels with electronic book applications; Teacher and student opinions. Cypriot Journal of Educational Science. 16(5), 28082818 https://doi.org/10.18844/cjes.v16i5.6369

Received from July 02, 2021; revised from August 25, 2021; accepted from October 24, 2021. (C)2021 Birlesik Dunya Yenilik Arastirma ve Yayincilik Merkezi. All rights reserved.

\begin{abstract}
Changes in the understanding of Education have led to the emergence of new approaches to teaching, strategies for teaching teachers, tools, methods and techniques. The purpose of this study is to evaluate the preparation of Kazakh novels for a book with electronic additions from the point of view of teachers and students. This study is based on high-quality research models, real scientific models. To collect data, the researcher created a semi-structured type of interview with the teacher and a semi-structured type of interview with the student. Study participants include 25 literature teachers from Almaty and Kazakhstan secondary schools and 122 students from various secondary schools. The study was conducted in the $2020-2021$ academic year. As a result of the study, part of reading Kazakh novels in print or electronic form was evaluated, and it was noted that the teacher likes printed stories. The results of students ' responses also show that reading printed Kazakh stories is higher than reading electronic Kazakh teaching.
\end{abstract}

Keywords: e-book; Kazakh stories; myth; Kazakh mythology; memories of students; memories of teachers.

\footnotetext{
${ }^{*}$ ADDRESS OF CORRESPONCE: Almas Naimanbaev, Candidate of philological sciences, doctoral student, Abai Kazakh National Pedagogical University, Almaty, Kazakhstan, Address: 13 Dostyk Ave., Almaty Email Address: almaz-88.80.17@mail.ru
} 


\section{Introduction}

In accordance with the needs of our century, a new understanding of Education moves from the past to the present. Changes in the understanding of Education have led to the emergence of new approaches to teaching, strategies for teaching teachers, tools, methods and techniques. In accordance with this, the problems of mythopoetics in artistic prose are also raised to a new methodological level. The problems of mythopoetics in artistic prose, which provide unlimited opportunities for the accumulation and reflection of the body, spirit and philosophy of human thought in general, occupy a special place in the field of literature. Writers have eaten this inexhaustible source, universal ideas and moral problems in mythopoetics are perfectly combined with the acute and urgent problems of our time. There is reason to believe that the appearance of Legends and legends in Kazakh prose is a unique phenomenon in the work of writers. Of course, despite the fact that religious and mythological motives had a great influence on the development of the Kazakh literary process in the twentieth century, its development was not uniform. Mythological network of the twentieth century. In the 1930s and early 60s, it was interrupted by ideological reasons that dominated literature, and later, since the 1970s, this continuity in Kazakh prose continued.

In the prose works of Kekilbayev, Isabekov, Magauin, Doszhanov, Bokeev, Sanbayev of the 1970s (Kazakh literature of the 19th century in the kazakh language, n.d.), the Kazakh master of artistic expression continues the epic metaphorical continuation and connection with ancient folklore and mythological culture in the early works of Auezov. Mythologism in Kazakh prose grew out of the works of writers Auezov, Mukanov, Musrepov and others, expanded its artistic horizons, and the tradition of using mythopoetic forms in modern Kazakh literature became more complex (Takirov et al., 2019).

In Kazakh literature, the works of Kekilbayev ("Steppe ballads", "The end of the legend"), Bokeev ("Snow White", "Muztau"), Sanbayev ("Longing for Legend", "Many-death"), Iskakbay ("The Legend of shame") and others are distinguished by a special "Game" style, blurring genre boundaries, the ability to go beyond the former aesthetic and ideological norm ((Kazakh literature of the 19th century in the kazakh language, n.d.). Consequently, today, changes in the world of education are accompanied by rapidly developing technologies and have led to the formation of educational materials and an educational environment with the integration of technologies. The technology-integrated educational environment creates new paradigms in education, including in the field of literature (Yang and $\mathrm{Wu}, 2012$ ).

As a result of the introduction of technologies into the educational environment and educational content and the expansion of the opportunities offered, the number of studies on the integration of technologies into education in the field of literature on the problems of mythopoetics in artistic prose is increasing day by day (Vogt, Tilya and Van den Akker, 2009). Among them, in our research work, we suggest studying the history of Kazakhstan on the topic of teaching using applications for e-books; feedback from teachers and students.

\subsection{Theoretical and conceptual framework}

The impact of technological developments on society has become one of the most discussed topics of today's world. Views and solutions regarding both the transformation in technological advances and their impact and consequences on the social structure are developing in parallel with technological progress (Pektas, 2017).

Information and Communication Technologies have been developing rapidly in recent years, called the Information Age. Accordingly, the necessity of people to keep up with this technology has arisen. Thanks to emerging new technologies, people can meet their needs quickly. Education is one of the areas where information and communication technologies are most needed. In addition, serious problems may arise if individuals working in the field of education do not follow today's technologies carefully (Sarikaya and Yarimsakalli, 2020).

Today, the so-called 'traditional education system' has a uniform, teacher-centered, book-bound and punishing reward system (Turk and Sari, 2017). The transfer of new technologies to educational environments 
has added a new dimension to the understanding of education, but it has also brought with it a changing understanding of online reading, from reading and digging in printed books. A learning teaching activity using only printed resources is no longer enough for today's world, and online resources have become an important part of being able to carry out effective learning teaching activities. However, the integration of technology into education is being carried out behind the planned process, and although the use of technology in daily life of adults and children is increasing rapidly, technology in education is not yet widely available in various classrooms from elementary to high school (Hutchison and Reinking, 2011).

However, technology integration is an important component in the education reforms of many countries around the world, and the integration of technology into learning-teaching activities has accelerated (Chen, 2010). In the 21st century education concept, reading activities are carried out through tools such as computers, tablets, mobile phones and billboards, except for tools such as books, magazines and newspapers. Multiple electronic media such as animation, video, pictures, graphics, photos, interactive images and audio stories in digital internet environments constitute an important alternative to printed books (Mayer and Moreno, 2003).

The term electronic book (e-book) is derived by Van-Dam and generally expressed as tools that store and transmit writings and images via electronics. (Huang, 2014). According to Vassiliou and Rowley (2008), ebooks are defined as digital objects that have the characteristics of traditional books.

Individuals with traditional literacy skills have difficulty performing effective reading and writing in digital environments with these skills. Gaining technology-based literacy skills is a prerequisite for effective literacy in digital environments. Therefore, technology causes differences in the conventional concept of literacy, necessities an extraordinary field of competence and the need to meet these requirements is increasing day by day (Dagtaş, 2013). The use of digital resources in the field of education is seen as an important tool in the development of students' language skills (Mouri and Rahimi, 2016).

With the rapid development of technology, communication technologies have rapidly penetrated daily life (Gunaydin, 2017). Dagtas (2013) reveals the fact that individuals need to add technology-based literacy skills alongside traditional literacy skills in order to travel the same level as other individuals without facing digital fragmentation in the information society.

The literary and subcultural phenomenon of Kazakh literature includes high literature, mass literature and "nonfiction" literature. The main features of modern children's literature include international character, social conformity, gender targeting, two-way, sequenction, connection with cinema and computers, playing games, and the transformation of traditional literary genres for children and adolescents (Fictionzov et al., 2021). Today, it is seen that the act of reading novels called literary texts is also reshaped by the influence of digital technologies. This new reading environment, where access to information sources through the Internet is enriched, is supported by electronic books, opening the doors of a new world to students. Considering the world of electronic books, which has opened its doors in recent years, it is considered that teaching Kazakh novels with electronic book applications is an important requirement.

\subsection{Related research}

Research in the field of the effective use of electronic books in learning reveals that digital books have been an effective material in recent years. In the Dagtas (2013) survey; he noted that teachers have a positive attitude regarding the use of digital texts in digital books in the educational environment. In the study, teachers found that digital books; they agreed that it contributes to education in terms of preventing paper waste, getting rid of the hassle of carrying books, rapid access, diversity of resources and gaining the habit of reading screens. Aktas and Yurt (2017), in their research; they evaluated the effects of the use of digital stories as learning materials on the student. As a result of the research, it was revealed that digital stories have a positive effect on academic success, motivation and memory. 
In their work, Duran and Topbasoglu (2015) evaluated the effect of narrative texts on understanding reading environments (from printed or digital-interactive books) and student opinions on digital-interactive books. As a result of the research, the average comprehension score of students reading from a digitalinteractive book was 1.2 points higher than the average comprehension score from printed material.

In their research, Smeda, Dakich and Sharda (2014) explored the pedagogical aspects of digital storytelling and the impact of digital stories on teachers and students. As a result of the research, it was revealed that digital stories are one of the innovative pedagogical approaches that can involve students in deep and meaningful learning.

Bozkurt and Bozkaya (2013) discussed the function of electronic books from the past to the present. Although the use of electronic books has many advantages, the researchers found that although it is not preferred at the level expected from the age of technology for some reasons such as emotional habits, lack of knowledge, lack of hardware.

\subsection{Purpose of the research}

The purpose of this research is; To evaluate the teaching of Kazakh novels through electronic book applications in terms of teacher and student opinions.

For this purpose, the following sub-objectives were searched for answers.

1. What is the teachers' perception of teaching Kazakh novels through electronic book applications?

2. What is the perception of students about learning Kazakh novels through electronic book applications?

\section{Method and Materials}

In this section, information about the method by which the research is carried out, who the working group consists of, what are the data collection tools, in what process the data is collected and by what methods are evaluated.

\subsection{Research methods}

This research is designed from qualitative research patterns in fact science pattern. Factology focuses on making common sense about a phenomenon from the life experiences of more than one person (Creswell, 2006). This approach refers to a methodological and detailed examination of how people perceive the researched phenomenon, how they define it, how they judge it, what they remember, what they give it and what they talk about it with others (Locke, 2002). In this study, it was appropriate to use the fact science pattern in this evaluation, since the opinions of teachers and students regarding the teaching of Kazakh novels with electronic book applications were evaluated.

\subsection{Participants}

In this research, easy-to-access situation sampling was used from purposeful sampling methods. The teachers and students who participated in the study were selected according to the easily accessible situation sampling technique from the sampling methods for the purposes. Easy-to-access case sampling is a frequently preferred type of sampling to delve deeper into qualitative research (Miles, Huberman and Saldana, 2014). Therefore, in this study, purposeful sampling was preferred instead of random sample selection. The 25 teachers who agreed to participate voluntarily in the research teach Literature in various secondary schools in Almaty. The 122 secondary school students who agreed to participate voluntarily in the study are also educated at various secondary schools in Almaty. Demographic characteristics of the participants of the study are included in the "Results" section.

\subsection{Data collection tools}


In the research, two semi-structured interview forms were used, teacher semi-structured interview form developed by the researcher and student semi-structured interview form for the purpose of collecting data. Validity and reliability studies of structured interview forms used in qualitative research are carried out at certain stages. In this context, valid; internal validity and generalability (external validity) and reliability audit should be carried out. The internal validity is how accurate the results of a study are, whether the purpose of the research and the social reality of those who participated in it are accurately reflected. Generalability (external validity) is generally accepted if the results of a research study can be applied to other similar environments and communities. Reliability in quantitative research is the same conclusion when the measuring tool is used more than once. But the main source of research in qualitative study is the researchers themselves. Therefore, even if the same measuring tool is used, a similar sample group is studied, and the same subject area is selected, the research data may not be repeatable. Therefore, the way to obtain a measure of reliability in qualitative research is to create an "audit trail" or "decision track". Recording the data collected during the research with an audit trail allows other researchers to follow the same process. The data presented by this method will be systematic and understandable (Daymon and Holloway, 2010). Accordingly, the answers to the questions in the semi-structured interview forms are categorized based on validity and reliability criteria. Semi-structured interview forms consist of 2 parts. The first section contains questions about the personal information of the teachers and students who participated in the research. In the second part, there are questions about the teaching of Kazakh novels by teachers and students through electronic book applications. Semi-structured interview forms are given at the end of the research in the form of Annex-1 and Annex-2.

\subsection{Data collection process}

The collection of data related to the research was carried out in two dimensions: interviews with both teachers and students. Two separate semi-structured interview forms were used parallel to each other for teachers and students. Taking into account the Covid-19 pandemic process, it was decided that it would be unhealthy to hold the talks face-to-face. The teacher semi-structured interview form was delivered to the teachers by e-mail and they were asked to fill out the form. Video calls were made with the students and the interview process was recorded. The students' responses were then transferred to semi-structured interview forms. It took about 2 months to collect the research data.

\subsection{Data analysis}

Responses to semi-structured interview forms used to collect data in the research were analyzed using the content analysis technique. Content analysis is the most common technique for analyzing qualitative research data. In content analysis, data is systematically presented by creating categories (Forman and Damschroder, 2007). The answers given by the participants to the questions in the semi-structured interview form were given by creating frequency and percentage tables.

\section{Results}

In this section, teachers and students' responses to semi-structured interview forms used in the research are evaluated.

\subsection{Teacher Semi-Structured Interview Form}

Table 1 provided demographic characteristics related to the gender and professional experience of the teachers who participated in the study.

Table 1: Distribution of teachers' gender and professional experiences

\begin{tabular}{llll}
\hline \multirow{2}{*}{ Experience } & \multicolumn{2}{c}{ Gender } & Sum \\
\cline { 2 - 3 } & Female & Male & Sum \\
\hline
\end{tabular}




$\begin{array}{lllc}\text { 1-4 Years } & 2 & 3 & 5 \\ \text { 5-8 Years } & 6 & 4 & 10 \\ \text { 9-12 Years } & 3 & 1 & 4 \\ 13 \text { Years + } & 4 & 2 & 6 \\ \text { Sum } & 15 & 10 & 25\end{array}$

In Table 1, the gender and professional experience distributions of the teachers participating in the research are given. Fifteen of the teachers surveyed were women and 0 were men. 5 teachers have 1-4 years, 10 teachers have 5-8 years, 4 teachers have $9-12$ years and 6 teachers have 13 years+ experience. A total of 25 teachers participated in the study.

Table 2 includes the opinions of the teachers who participated in the research on the benefits of teaching Kazakh novels through electronic book applications.

Table 2: Teachers' views on the benefits of teaching Kazakh novels through electronic book applications

\begin{tabular}{lll}
\hline Teacher Feedback & F & $\%$ \\
\hline Providing learning motivation & 19 & 76 \\
Providing a fun learning environment & 13 & 52 \\
Permanent learning & 11 & 44 \\
$\begin{array}{l}\text { Providing the student with ease of understanding what they } \\
\text { are reading }\end{array}$ & 7 & 28 \\
$\begin{array}{l}\text { Providing technological learning opportunities } \\
\text { Prevent paper waste }\end{array}$ & 5 & 20 \\
\hline
\end{tabular}

The teachers who participated in the study expressed their opinions on the benefits of teaching Kazakh novels through electronic book applications. $76 \%$ of teachers defined providing learning motivation, $52 \%$ providing a fun learning environment, $44 \%$ identify learning as permanent, $28 \%$ providing students with ease of reading comprehension, $20 \%$ providing technological learning opportunities and $16 \%$ identifying paper waste as beneficial.

Table 3 contains the opinions of the teachers who participated in the study on the limitations of teaching Kazakh novels through electronic book applications.

Table 3: Teachers' views on the limitations of teaching Kazakh novels through electronic book applications

\begin{tabular}{lll}
\hline Teacher Feedback & F & \% \\
\hline Not being able to access every book easily & 21 & 84 \\
Impairing eye health & 16 & 64 \\
Causing technology addiction & 14 & 56 \\
Difficulty in supplying reading tools & 5 & 20
\end{tabular}

The teachers who participated in the study expressed an opinion on the limitations of teaching Kazakh novels through electronic book applications. $84 \%$ of teachers defined not being able to easily access every book, $64 \%$ describing impaired eye health, $56 \%$ as causing technology addiction and $20 \%$ describing difficulty in obtaining reading tools as limitations. 
In Table 4, the frequency of teachers reading printed Kazakh novels and the frequency of reading electronic Kazakh novels are given.

Table 4: Frequency of teachers reading printed and electronic Kazakh novels

\section{Teacher opinions}

\begin{tabular}{lccccccccccc} 
& \multicolumn{10}{c}{$\mathrm{S}$} \\
\cline { 3 - 12 } & $\mathrm{F}$ & $\%$ & $\mathrm{~F}$ & $\%$ & $\mathrm{~F}$ & $\%$ & $\mathrm{~F}$ & $\%$ & $\mathrm{~F}$ & $\%$ \\
$\begin{array}{l}\text { Frequency of reading printed Kazakh } \\
\text { novels }\end{array}$ & 14 & 5 & 9 & 36 & 2 & 8 & - & - & 2 & 10 \\
$\begin{array}{l}\text { Frequency of } \\
\text { Kazakh novel }\end{array}$ & & 6 & & & & & & & 5 \\
\hline
\end{tabular}

The frequency of reading Kazakh novels in print or electronically was evaluated. Teachers read printed Kazakh novels; $56 \%$ always stated that $36 \%$ expressed sometimes, $8 \%$ rarely. The frequency with which they read electronic Kazakh novels; $25 \%$ always defined $44 \%$ as sometimes, $28 \%$ as rare and $4 \%$ as never.

\subsection{Student Semi-Structured Interview Form}

Table 5 contains demographics related to the gender of the students participating in the study and the class distribution in which they studied.

Table 5: Gender of students and the class distributions in which they study

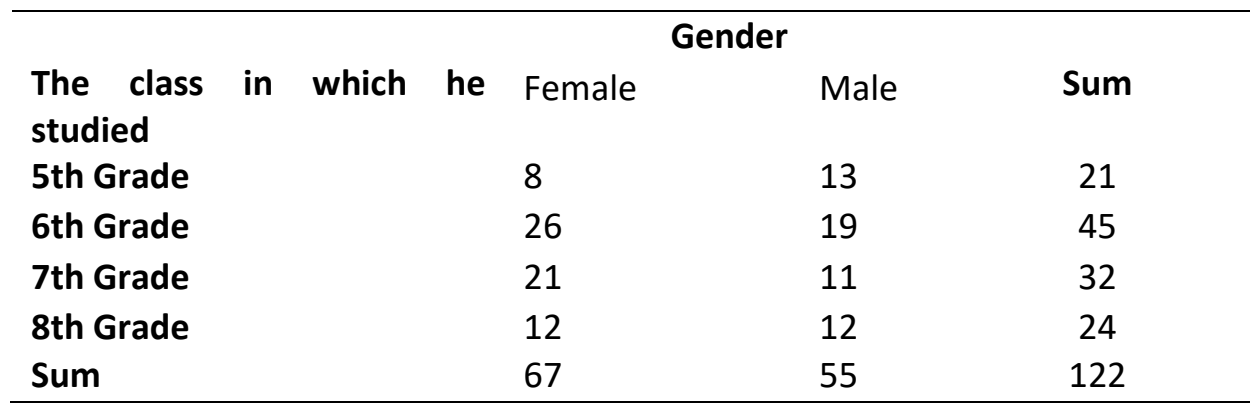

Table 5 provided gender and class distributions of the students who participated in the study. 21 of the students are 5th grade, 45 are 6th grade, 32 are 7th graders and 24 are 8th graders. Of the students surveyed, 67 were girls and 55 were boys. A total of 122 students participated in the study.

Table 6 contains the opinions of the students who participated in the study regarding reading electronic books.

Table 6: Students' views on reading electronic books

\begin{tabular}{|c|c|c|c|c|c|c|c|c|}
\hline \multirow[t]{2}{*}{ Student feedback } & \multicolumn{2}{|c|}{ Agree } & \multicolumn{2}{|c|}{ Undecided } & \multicolumn{2}{|c|}{ Disagree } & \multicolumn{2}{|c|}{ Sum } \\
\hline & $\mathrm{F}$ & $\%$ & $\mathrm{~F}$ & $\%$ & $\mathrm{~F}$ & $\%$ & $\mathrm{~F}$ & $\%$ \\
\hline $\begin{array}{l}\text { Electronic books increase motivation to } \\
\text { read }\end{array}$ & 82 & 67,2 & 7 & 5,8 & 33 & 27 & 122 & 100 \\
\hline Electronic books are easy to obtain & 14 & 11,5 & 26 & 21,3 & 82 & 67,2 & 122 & 100 \\
\hline
\end{tabular}


Naimanbaev, A., Satemirova, D. A., Alpysbay,T., Rakhat, S., Abdigazievich, B.\& Teaching Kazakh novels with electronic book applications; Teacher and student opinions. Cypriot Journal of Educational Science. 16(5), 2808-2818 https://doi.org/10.18844/cjes.v16i5.6369

\begin{tabular}{|lllllllll|}
\hline Electronic books are interesting & 91 & 74,6 & 3 & 2,4 & 28 & 23 & 122 & 100 \\
\hline $\begin{array}{l}\text { Electronic books negatively affect } \\
\text { health }\end{array}$ & 65 & 53,3 & 32 & 66,2 & 25 & 20,5 & 122 & 100 \\
\hline $\begin{array}{l}\text { Electronic books increase reading habits } \\
71\end{array}$ & 58,2 & 19 & 15,6 & 32 & 26,2 & 122 & 100 \\
\hline
\end{tabular}

The students who participated in the study were evaluated in 5 articles regarding reading electronic books. The students responded to the articles with "I agree", "I am undecided" and "I do not agree". Students increase the motivation to read electronic books; $67.2 \%$ agreed, $5.8 \%$ were undecided and $27 \%$ disagreed. Students, supplying electronic books is an event; $11.5 \%$ agreed, $21.3 \%$ said I disagreed and $67.2 \%$ disagreed. Students, electronic books are interesting; $74.6 \%$ agreed, $2.4 \%$ were undecided and $23 \%$ disagreed. Students, electronic book negative effects on health substance; $53.3 \%$ agreed, $66.2 \%$ said I disagreed and $20.5 \%$ disagreed. Finally, students increase their habit of reading electronic books; $58.2 \%$ agreed, $15.6 \%$ said I disagreed and $26.2 \%$ disagreed.

In Table 7, the frequency of reading printed Kazakh novels and the frequency of reading electronic Kazakh novels were given.

Table 7: Frequency of students reading printed and electronic Kazakh novels

\begin{tabular}{|c|c|c|c|c|c|c|c|c|c|c|}
\hline \multirow[t]{2}{*}{ Students' opinions } & \multicolumn{2}{|c|}{ Always } & \multicolumn{2}{|c|}{ Sometimes } & \multicolumn{2}{|c|}{ Rarely } & \multicolumn{2}{|c|}{ Never } & \multicolumn{2}{|c|}{ Sum } \\
\hline & $\mathrm{F}$ & $\%$ & $\mathrm{~F}$ & $\%$ & $\mathrm{~F}$ & $\%$ & $\mathrm{~F}$ & $\%$ & $\mathrm{~F}$ & $\%$ \\
\hline Frequency of reading printed Kazakh & 4 & 36 & 62 & 50 & 1 & 10, & 3 & 2,5 & 12 & 10 \\
\hline novels & 4 & & & 8 & 3 & 7 & & & 2 & 0 \\
\hline reading electronic & 1 & 9,8 & 17 & 14 & 6 & 55 , & 2 & 20,5 & 12 & 10 \\
\hline Kazakh novel & 2 & & & & 8 & 7 & 5 & & 2 & 0 \\
\hline
\end{tabular}

The frequency of reading Kazakh novels in print or electronically was evaluated. Students read printed Kazakh novels; $36 \%$ always expressed $50.8 \%$ sometimes, $10.7 \%$ rarely and $2.5 \%$ never. Students read electronic Kazakh novels; $9.8 \%$ always defined it as $14 \%$ sometimes, $55.7 \%$ rarely and $20.5 \%$ never.

\section{Discussion}

In the research, teachers' views on the benefits of teaching Kazakh novels with electronic book applications are in the form of providing learning motivation, providing a fun learning environment, providing the student with ease of reading comprehension, providing technological learning opportunities and preventing paper waste. The opinions of the teachers who participated in the study on the limitations of teaching Kazakh novels with electronic book applications; not being able to easily access every book, impairing eye health, causing technology addiction and having difficulty in providing reading tools. In their study, Duran and Ertuğrul (2012) stated that electronic books have advantages such as supporting content with visuals and sound, interactive training, protection from paper waste and increasing teacher motivation. In the study, health threats, lack of infrastructure and service, lack of readiness and developmental differences of students are listed as disadvantages of electronic books.

When the frequency of reading Kazakh novels in print or electronically was evaluated, it was found that teachers' tendency to read printed books was higher than their tendency to read electronic books. In their study of the use of electronic books in social sciences, Chrzastowski and Wiley (2015) found that the reading rates of printed books were higher in the reading rates of electronic books. Dyson and Haselgrove (2001) noted in their research that the most common finding regarding electronic books is that reading from paper is more functional than reading from the screen, and reading from the screen is slower than reading from paper. 
Students' views on reading electronic books are that electronic books increase reading motivation, that it is not easy to obtain electronic books, that electronic books are interesting, negatively affect health and increase reading habits. In his study, Jeong (2012) found that electronic books cause eye strain.

The frequency of reading Kazakh novels in printed or electronic media by the students participating in the research was evaluated, and it was concluded that the rate of reading the printed novels of the students was higher than the rate of reading the electronic novels. Martin and Platt (2001) also revealed in their research that students prefer printed books rather than electronic books. Shelburne (2009), on the other hand, revealed in her research that the usability of electronic books is gradually increasing, and students' interest in electronic books has started to change in a positive way compared to the past.

\section{Conclusion}

In the last few years, when distance education has become a necessity rather than a choice due to the Covid-19 pandemic, the electronic learning performance of students has become extremely important.

In this direction, in this research, it is aimed to evaluate the teaching of Kazakh novels with electronic book applications in terms of teacher and student views. Research results teachers; They claimed that teaching Kazakh novels with electronic book applications is beneficial in terms of providing learning motivation, providing a fun learning environment, permanent learning, providing ease of reading comprehension, providing technological learning opportunities and preventing waste of paper. The limitations of teaching Kazakh novels with electronic book applications were defined by the teachers as not being able to reach every book easily, disrupting eye health, causing technology addiction, and having difficulty in obtaining reading tools. The students who participated in the research stated that electronic books increase the motivation to read, it is not easy to obtain electronic books, electronic books are interesting, affect health negatively and increase reading habits.

In addition, when the frequency of reading Kazakh novels in printed or electronic media was compared, it was found that teachers preferred printed novels more. The findings obtained from the answers of the students also show that they have a higher tendency to read printed Kazakh novels than to read electronic Kazakh novels. Although teachers and students are more likely to read printed books, research findings reveal that teachers read more Kazakh electronic novels than students.

\section{Recommendations}

In line with the results obtained from the research; reveals that teachers and students have a weak attitude in teaching Kazakh novels through electronic books. Consequently;

1. Giving in-service training seminars on teachers' interest in electronic books and their use in education,

2. Removing the barriers to students' access to electronic books,

3. Reorganizing the course content to improve students' e-book reading habits

It is thought that teaching Kazakh novels with electronic book applications will become widespread when these requirements are eliminated.

\section{References}

Aktas, E., \& Yurt, S. U. (2017). Effects of digital story on academic achievement, learning motivation and retention among university students. International Journal of Higher Education,6(1), $180-196$. https://eric.ed.gov/?id=EJ1126025 
Chen, R. J. (2010). Investigating models for preservice teachers' use of technology to support student-centered learning. Computers \& Education, 55(1), 32-42. https://doi.org/10.1016/i.compedu.2009.11.015

Chrzastowski, Tina E. and Lynn N. Wiley. 2015. “E-book Use and Value in the Humanities: Scholars' Practices and Expectations." Library Resources and Technical Services, 59(4), p. 172-86. https://scholarcommons.scu.edu/cgi/viewcontent.cgi?article=1041\&context=library

Creswell, J. W. (2006). Qualitative Inquiry and Research Design: Choosing among Five Approaches [with CDROM]. SAGE Publications (CA). https://eric.ed.gov/?id=ED500417

Dagtas, A. (2013). Opinions of teachers on printed page and screen reading preferences and the use of electronic text in education. Electronic Turkish Studies, 8(3). http://www.ajindex.com/dosyalar/makale/acarindex1423933020.pdf

Daymon, C., \& Holloway, I. (2010). Qualitative research methods in public relations and marketing communications. Routledge. https://doi.org/10.4324/9780203846544

Duran, E., \& Ertugrul, B. (2012). Opinions of primary school teachers about electronic textbooks. Turkish Journal of Educational Sciences, 10(2), 347-365. https://dergipark.org.tr/en/pub/tebd/issue/26137/275283

Duran, E., \& Topbaşoğlu, N. (2015). Digital-interactive narrative texts and understanding. Electronic Turkish Studies, 10(11). https://eds.a.ebscohost.com/eds/pdfviewer/pdfviewer?vid=0\&sid=6820c8b3-ef064ec0-86f4-4f5b21b34259\%40sdc-v-sessmgr01

Dyson, M. C., \& Haselgrove, M. (2001). The influence of reading speed and line length on the effectiveness of reading from screen. International Journal of Human-Computer Studies, 54(4), 585-612. https://doi.org/10.1006/ijhc.2001.0458

Forman, J., \& Damschroder, L. (2007). Qualitative content analysis. In Empirical methods for bioethics: A primer. Emerald Group Publishing Limited. https://doi.org/10.1016/S1479-3709(07)11003-7

Gunaydin, N. (2017). The appearance of computer/Internet dependency in Turkey. New Trends and Issues Proceedings on Advances in Pure and Applied Sciences. [Online]. 08, pp 45-49. Available from: www.propaas.eu https://doi.org/10.18844/gjapas.v0i8.2838

Huang, T. (2014). A study on the effects of interactive e-books on Taiwan high/vocational school students' reading comprehension. Vocational School Students' Reading Comprehension (July 6, 2014). https://papers.ssrn.com/sol3/papers.cfm?abstract id $=2462830$

Hutchison, A., \& Reinking, D. (2011). Teachers' perceptions of integrating information and communication technologies into literacy instruction: A national survey in the United States. Reading Research Quarterly, 46(4), 312-333. https://doi.org/10.1002/RRQ.002

Jeong, H. (2012). A comparison of the influence of electronic books and paper books on reading comprehension, eye fatigue, and perception. The Electronic Library, 30(3), 390-408. https://doi.org/10.1108/02640471211241663

Turgunov, Y., Abdimomynov, Y., Smanov, Baktiyar., Shakhanova, R., Naimanbaev, A., Koch, K. (2019). The problem of elimination of illiteracy by writing textbooks in the steppe. Opción, Año 35, No. 88 (2019): 543-566ISSN 1012-1587 / ISSNe: 2477-9385 http://produccioncientificaluz.org/index.php/opcion/article/view/24216Kazakh literature of the 19th century in the kazakh language. Kazakh literature at the beginning of the 20th century. (n.d.). Retrieved November 15, 2021, from https://moscsp.ru/en/kazahskaya-literatura-19-veka-na-kazahskom-yazykekazahskaya.html .

Kurguzov, O., Degteva, V., Sedov, S., Usachev, A., Mikheeva, T., Egorushkina, A., ... \& Dzhumageldinova, D. (2021). Genre changes of modern children's story in Kazakhstan Russian literature. BBK 83.3 (5 Kaz) P 78 Genel Yayın Yönetmeni , 84. https://abaiuniversity.edu.kz/docs/215 1 compressed.pdf\#page=85 
Locke, K. (2002). Qualitative research and evaluation methods. Organizational Research Methods, 5(3), 299. https://www.proquest.com/docview/195065571?pq-origsite=gscholar\&fromopenview=true

Martin, L. A., \& Platt, M. W. (2001). Printing and screen reading in the medical school curriculum: Guttenberg vs. the cathode ray tube. Behaviour \& Information Technology, 20(3), 143-148. https://doi.org/10.1080/01449290110048043

Mayer, R. E., \& Moreno, R. (2003). Nine ways to reduce cognitive load in multimedia learning. Educational psychologist, 38(1), 43-52. https://doi.org/10.1207/S15326985EP3801_6

Miles, M. B., Huberman, A. M., \& Saldana, J. (2014). Qualitative Data Analysis: A Methods Sourcebook. SAGE Publications Ltd (CA). https://eric.ed.gov/?id=ED565763

Mouri, S. \& Rahimi, A. (2016). The impact of computer-assisted language learning on Iraniana EFL students' vocabulary learning. Global Journal of Foreign Language Teaching. 6(4), 210-217. https://doi.org/10.18844/gjflt.v6i4.1673

Pektas, D. (2017). Investigation of relations among preschool children and their parents' use of technological devices and reading habits. New Trends and Issues Proceedings on Humanities and Social Sciences. [Online]. 01, pp 409-416. https://doi.org/10.18844/gihss.v3i1.1795

Sarikaya, H., \& Yarimsakalli, M. S. (2020). The effects of robotics programming on secondary school students' problem-solving skills. World Journal on Educational Technology: Current Issues. 12(4), 348 -360. https://doi.org/10.18844/wjet.v12i4.5185

Shelburne, W. A. (2009). E-book usage in an academic library: User attitudes and behaviors. Library collections, acquisitions, \& technical services, 33(2-3), 59-72. https://doi.org/10.1080/14649055.2009.10766234

Smeda, N., Dakich, E., \& Sharda, N. (2014). The effectiveness of digital storytelling in the classrooms: a comprehensive study. Smart Learning Environments, 1(1), 1-21. https://link.springer.com/article/10.1186/s40561-014-0006-3

Takirov, S., Zharylgapov, Z., Rustemova, Z., Syzdykova, B., \& Zhumageldin, Z. (2019). Totalitarian and kazakh literary criticism. Humanities \& Social Sciences Reviews, 7(6), 118-122. https://core.ac.uk/download/pdf/268005619.pdf

Turk, S. A. \& Sari, R. M. (2017). T Alternative education approaches and their effects on the learning space. International Journal of Innovative Research in Education. 4(4), 202-214. https://doi.org/10.18844/ijire.v4i4.3432

Vassiliou, M. and Rowley, J. (2008), "Progressing the definition of "e-book" ", Library Hi Tech, Vol. 26 No. 3, pp. 355-368. https://doi.org/10.1108/07378830810903292

Voogt, J., Tilya, F., \& van den Akker, J. (2009). Science teacher learning of MBL-supported student-centered science education in the context of secondary education in Tanzania. Journal of Science Education and Technology, 18(5), 429-438. https://link.springer.com/content/pdf/10.1007/s10956-009-9160-8.pdf

Yang, Y. T. C., \& Wu, W. C. I. (2012). Digital storytelling for enhancing student academic achievement, critical thinking, and learning motivation: A year-long experimental study. Computers \& education, 59(2), 339352. https://doi.org/10.1016/i.compedu.2011.12.012 